Borer, T.A., and Mills, K. (2011) Explaining Post-Apartheid South African Human Rights Foreign Policy: Unsettled Identity and Conflicting Interests. Journal of Human Rights, 10 (1). pp. 76-98. ISSN 1475-4835

Copyright (C) 2011 Taylor and Francis

A copy can be downloaded for personal non-commercial research or study, without prior permission or charge

The content must not be changed in any way or reproduced in any format or medium without the formal permission of the copyright holder(s)

When referring to this work, full bibliographic details must be given

http://eprints.gla.ac.uk/44291/

Deposited on: 9 Jan 2014

Enlighten - Research publications by members of the University of Glasgow http://eprints.gla.ac.uk 


\title{
Explaining Post-Apartheid South African Human Rights Foreign Policy: Unsettled Identity and Conflicting Interests ${ }^{1}$
}

\author{
Tristan Anne Borer (Connecticut College) \\ Kurt Mills (University of Glasgow)
}

Forthcoming in Journal of Human Rights (2011)

(accepted, pre-copy-edited version - Sepember 2010)

On February 11, 1990 a captivated world watched as Nelson Mandela, at the time the world's longest-serving political prisoner and a preeminent symbol of human rights repression, walked out of a South African prison after 27 years of captivity. Less than four years later, in April 1994, South Africans of all racial, political, and socioeconomic backgrounds went to the polls by the millions to elect Mandela as their president, in the country's first ever democratic election. With this election the system of apartheid - one of the most highly institutionalized systems of segregation known to humankind - was brought to a resounding end. The forty-five years of apartheid rule (along with the over three hundred years of segregation that preceded it) were accompanied by human rights abuses that were similarly unparalleled. With its collapse came the hope, and indeed the expectation, by South Africans and the world alike, that South Africa's policies, both domestic and foreign, would be henceforth guided by human rights principles. On the international level, as South Africa transitioned from pariah to global participant, expectation abounded that it would be the beacon of light for oppressed peoples around the world, serving as a regional — even global — force for good, undergirded by a new commitment to ethical foreign policies. There was an expectation, in other words, that South Africa's past would be predictive of its future.

This early optimism, it turns out, was premature. The reality has been somewhat less positive than human right activists had hoped for; South Africa's foreign policy since 1994 might best be described as one of disparity between commitment and action. From its support of President Robert Mugabe of Zimbabwe even in the face of a growing humanitarian crisis, to its engagement in refoulement (the forced return of refugees) by turning away almost all refugees at its borders, to its overtly blocking United Nations' actions on behalf of human rights in such places as Burma/Myanmar, Tibet, and East Timor, South Africa has frequently been unwilling or unable to act as a global standard bearer of human rights. In many ways, South Africa has turned out to be a disappointment to those who expected much more in the way of linkage between ethics and policy.

This reality gives rise to two questions. First, why did the world expect South Africa to act in a certain way internationally? In other words, what led to the expectation that South Africa's history of human rights abuses would translate into a future of human rights activism when democracy arrived with the election of Mandela's African National Congress (ANC)? Secondly, why has South Africa been so disappointing in this area? In this article, we try to answer these questions. We first address the question of why the world expected South Africa's past to be predictive of its future. We then review the theoretical debates over various "logics" that can be said to be drivers of states' foreign policy decisions, making some preliminary observations about which theories appear best to describe South African behavior. We next examine some of South Africa's most notorious contradictory foreign policy decisions (concentrating primarily on 
the period from 1994 through the end of Thabo Mbeki's presidency), demonstrating the gap between anticipated versus actual behavior, and then analyze scholarly literature on South Africa's foreign policy since 1994, with the aim of categorizing possible explanations for South Africa's apparently contradictory international behavior. We identify three sets of influences on South Africa's post-apartheid foreign policy - competing ideologies (including democracy, antiimperialism, and pan-Africanism) which all fall under the heading of the African Renaissance, continental constraints (African unity and its role as a regional power), and global constraints (economic imperatives and expectations placed on it by virtue of its ambitions to be a global player). The paper then returns to our theoretical analysis, in which the South African case is examined from the larger metatheoretical context of the rationalist/constructivist debate, and we conclude with some thoughts about the paradoxes of South Africa's foreign policy.

\section{"Human Rights Will Be Our Core Concern"}

Why did South Africans and the world expect South Africa to become a particularly ethical international actor, one that would put human rights at the center of its foreign policy? As James Barber points out $(2005,1095)$, stating one position and then taking a different one is hardly

unique to South Africa. Still, South Africa does seem to have been held to a higher standard than most countries. Why? One answer is that South Africa told the world it would be just such an actor; a second is that South Africa's history seemed to predispose it towards a particular way of acting. When this did not seem to happen, Barber argues $(2005,1096)$, in South Africa "the gap between principle and practice emerged perhaps more clearly than in other cases."

\section{A Self-Described Beacon of Hope}

The world might be forgiven for expecting South Africa to assume a mantle of morality in foreign policy, since Nelson Mandela - early in South Africa's democratic transition-gave every indication to a watching world that it would. In a Foreign Affairs article that appeared months before his 1994 election, Mandela $(1993,87)$ listed the pillars upon which South Africa's future foreign policies would rest: the belief that issues of human rights are central to international relations and the understanding that they extend beyond the political, embracing as well the economic, social and environmental. Mandela summed up his vision of South Africa's role in fostering a more just and humane world by stating, "South Africa's future foreign relations will be based on our belief that human rights should be the core concern of international relations, and we are ready to play a role in fostering peace and prosperity in the world we share with the community of nations" (Mandela 1993, 97). ${ }^{2}$ Laurie Nathan goes so far as to say (2005, 364) that "a principled commitment to democracy and respect for human rights was the essence if not the totality of President Mandela's foreign policy."

The ANC Working Group (1994, 221-24) confirmed Mandela's commitment in the vision and foreign policy goals it announced as it prepared to take power:

Although a more dangerous place, the world dare not relinquish the commitment to Human Rights. This has a special significance for South Africa; our struggle to end apartheid was a global one and we believe that change has enhanced the necessity for a worldwide Human Rights campaign. South Africa will play a central role in this campaign. . . The rise of a non-racial, non-sexist democratic South Africa from the ashes of apartheid will not terminate our quest for human rights. South Africa will immediately become a fully-fledged and vital member of the family of nations who hold human rights issues central to foreign policy. 
Some of the steps we will take are symbolic but, in our efforts to canonise human rights in our international relations, we regard them as far more than this." (emphasis added)

South Africa's stated priorities changed little over the next ten years. In 2004, its Department of Foreign Affairs published a strategic plan listing its foreign policy principles, with commitments to the promotion of human rights and democracy and to justice and international law in the conduct of relations between nations appearing as the top two (Nathan 2005, 362). Observing Mbeki's first term of office, Nathan $(2005,362)$ notes "given the political distance between 1994 and 2004, it is striking that the current principles are virtually identical to those formulated by the African National Congress (ANC) at the time it came to power."

In sum, the ANC came to power bathed in a sense of international goodwill and domestic self-confidence. It projected itself to the world as a righteous state, assuming that "having set South Africa to rights, it could make a similar contribution to the world" (Barber 2005, 1096). In other words, the world expected South Africa to make human rights a priority in foreign policy precisely because South Africa told the world that it would.

\section{Past as Prologue}

Other reasons for the expectation that South Africa would consistently put the promotion of human rights at the forefront of its policies are its history and the background of its postapartheid leaders. Having been the victims of brutal and gross violations of human rights, these new leaders would presumably ensure that South Africa would never again engage in or condone such abuses. As Nathan states $(2005,362)$, the idealist, internationalist, and emancipatory orientation of the new leadership was "derive[d] from and framed by the liberation struggle." Thus its history as an abuser would ensure its future as a promoter and protector of human rights. Paul-Henri Bischoff $(2003,189)$ puts it most succinctly: "There are those who expected the ANC as a national liberation movement assuming power to adopt only those values and objectives in line with its own immediate history of struggle." Again, Mandela led the way in fostering this expectation. In his Foreign Affairs article, he invoked South Africa's past to presage its future ethical policies, stating:

The anti-apartheid campaign was the most important human rights crusade of the post-World War II era. Its success was a demonstration, in my opinion, of the oneness of our common humanity: in these troubled times, its passion should not be lost. Consequently, South Africa will not be indifferent to the rights of others. Human rights will be the light that guides our foreign affairs (Mandela 1993, 88).

Indeed, Chris Alden and Garth le Pere $(2004,284)$ argue that Mandela very consciously drew on his country's apartheid history to explain its foreign policy decisions: "by incorporating the experiences of the anti-apartheid struggle into the conduct of foreign policy, the ANC leader sought to imbue the practice of international affairs with an explicit orientation towards the promotion of civil liberties and democratisation."

The notion that South Africa's present behavior can be explained by its past pertains not only to its history of apartheid-era abuses and the struggle against them but also to the quality of South Africa's negotiated transition from authoritarianism to democracy. Whereas the world expected a bloodbath, South Africa delivered a relatively bloodless transfer of power, an event which continues to be described as the "South African miracle." One outcome of the miracle, of course, was the South African constitution, widely regarded as perhaps the most human-rightsgranting document of its kind in the world. As a result of its constitution with its expansive bill 
of rights and a Constitutional Court to adjudicate it, South Africa saw itself and was seen by the world as a country that would advocate for human rights. Bischoff has noted that in light of its past, South Africa had certain expectations thrust upon it regarding its future role. As a result of its negotiated settlement and its emergence as a constitutional democracy, Bischoff claims (2003, 184), South Africa was "afforded the opportunity to project itself as a country that stood for inclusivity and that could function as an honest broker, a diplomatic niche player, projecting southern concerns towards an evolving (neo-)liberal world order." Again, South African leaders have consciously cultivated this perspective, as Alden and le Pere (2004, 283) note, "Nelson Mandela and his successor Thabo Mbeki have sought to invigorate the conduct of international affairs with reference to South Africa's unique transition and moral stature." Alden and le Pere sum up these twin expectations - of South Africa anointing itself as the leader in adopting a human rights-based foreign policy and of having this mantle thrust upon it: "By virtue of its 'miraculous' transition, South Africa was expected by the international community to 'punch above its weight,' a view that South African officials tended to encourage” (294).

\section{Identities and Interests: The Theoretical Debates}

How might international relations theory help us explain the South African case, and how might the South African case help us refine existing theory? The question of expected foreign policy behavior has most recently been framed by the rationalist-constructivist metatheoretical debate. These two perspectives predict very different foreign policy behavior. The so-called rationalist side argues that state interests are fixed and that states pursue those interests in a rational manner to maximize their achievement. There may be a debate among different strands of rationalists, from those who argue that the anarchical nature of the international system is inherently conflictual, making cooperation impossible (Waltz 1979), to those who maintain that the anarchical nature of the international system does not preclude cooperation and, in fact, that cooperation may be the most rational path to achieving the national interest, even though the institutions themselves may have a limited impact on changing state behavior (Glaser 1994). They both agree, however, that such interests are the same for all states. States are deemed to be working within a "logic of consequences" (Finnemore 1996, 28-31) - they are pursuing predetermined state interests (Finnemore 1996, 7-10), focusing solely on the consequences of their actions (i.e., how the actions help them achieve their goals) rather than worrying about how their actions cohere with international norms and other expectations (Krasner 1999, 3-6; Keohane 1986; Scott, Reynolds, and Lott 1995, 33-38).

Constructivists, on the other hand, argue that state preferences are not fixed. They are related to a state's identity, which may change as a result of socialization in the international realm (Risse 2002, 599-600) as well as domestic change. Constructivists still expect states to pursue their interests - no state will act against what it sees as its national interest - but the interpretation of that national interest will vary from state to state and may change over time depending upon changes in their perceived identities. Thus, states are seen as operating according to a "logic of appropriateness" (Finnemore 1996, 5-7, 29) - engaging in behavior that is determined either by what is expected of them by the international community (such as complying with human rights norms), or by what they expect of themselves as a result of selfperceptions of their identity (as, for example, a country that protects human rights) (see Mills and Lott, 2007).

Frequently these two perspectives are portrayed as in absolute conflict - either rationalism explains state behavior or constructivism provides the best insight into how a state behaves on 
the international scene. Yet, it is clear that neither perspective can adequately explain how states act internationally (Risse 2002, 597). States are embedded in a community of states with many and frequently contradictory - norms, rules, and laws that create expectations for how states should act. Sometimes - in fact, frequently - these expectations are confounded. Mills and Lott (2007), drawing on March and Olsen (1998), maintain that these two metatheoretical explanations can interact in different ways. First, one finds situations where both the logics of consequences and appropriateness seem to play a part in determining state action in a particular circumstance - states seem to be acting on traditionally defined state interests while also reacting to external expectations. They label this a "concurrent" logic ordering. In addition, Mills and Lott argue $(2007,503)$ that state behavior may be structured by one or the other of the logics either by constituting state identity and interests (the logic of appropriateness) or by constraining state behavior (the logic of consequences):

In the first instance, norms constitute the decision-making environment of states. In the second, perceived state interests constrain the range of choices open to the state. The mere fact that a response must be made to a particular international issue may be a reaction to some normative concern in the international arena. Alternatively, a logic of consequences may constrain the range of normatively appropriate actions. Self-interest explanations may constrain a normative process.

To these three ordering logics - consequences, appropriateness, and concurrence - Risse (2000) and Mills (2009) add a fourth, the "logic of arguing." This logic tends to come into play when a state's interests are not settled:

Argumentative and deliberative behavior is as goal oriented as strategic interaction, but the goal is not to attain one's fixed preferences, but to seek a reasoned consensus. Actors' interests, preferences, and the perceptions of the situation are no longer fixed, but subject to discursive challenges. Where argumentative rationality prevails, actors do not seek to maximize or to satisfy their given interests and preferences, but to challenge and to justify the validity claims inherent in them - and they are prepared to change their views of the world or even their interests in light of the better argument (Risse 2000, 7).

Further, the logic of arguing may be constitutive, but in situations in which there are conflicts between norms or in which norms are in flux, states may feel a conflict between norms and may move between them in unpredictable ways.... There may be real conflict between... sets of norms that will make the normative milieu more complex.... while norms constitute the decision-making environment of states, the evolving and ongoing conflictive nature of different norms complicates the relationship between them, opening up more space for "argument" among states (Mills 2009, 542).

Thus, we may see situations in which state action is primarily determined by traditional state interests, where state behavior appears to be guided more by internal and external expectations of what the state should do, where such expectations conflict and thus lead to confusing and apparently paradoxical behavior, or where both traditional state interests and expected behavior simultaneously explain a particular action or set of actions on the part of a state. Each of these dynamics can be found in the foreign policy of post-apartheid South Africa.

\section{South Africa: A Constructivist State with "Neo-Neo" Tendencies?}


Both South Africa's domestic historical development and the international milieu in which it took place would seem to mitigate in favor of a particular way of acting that is at odds with much of its actual behavior. Yet, those expecting such consistent behavior ignore other powerful forces which push against such expectations. The debate might be framed by asking whether South Africa is an exceptional state or a regular state - or both. As Peter Vale and Ian Taylor (1999, 630) argue, "South Africa's foreign policy... reflects a dual image - a Ying and Yang as it were - between being both 'something special', and 'just another country.'"

\section{Historically Exceptional}

The election of Nelson Mandela in 1994 marked the end of decades of struggle - both domestic and international - that brought the end of apartheid. Apartheid defined South Africa both domestically and internationally. Its domestic policies led to an aggressive foreign policy in southern Africa dedicated to defending apartheid from its neighboring states and from antiapartheid activists who found refuge in such states. They also led to international movements and foreign policies on the part of other states dedicated to ending apartheid. The minority white government's understanding of South Africa's identity led it to pay little attention to international expectations for many years.

According to rationalist accounts of state behavior, states are not supposed to radically change their understandings of themselves and their interests. Yet, this is exactly what happened when the ANC came into power in 1994. Since its founding in 1912, the ANC had been dedicated to creating a nonracial South Africa. When it came to power it sought to make this a reality, dramatically transforming the South African state. Its domestic struggle also translated into a vision of South Africa where human rights are respected, and its constitution is one of the most protective of human rights on the planet. Moreover, as we will demonstrate, the ANC sought to expand this orientation into the international realm by making human rights a key driver of its foreign policy. The international support given to the ANC and the anti-apartheid movement by the international community created a debt that South Africa felt it had to repay in kind by supporting such human rights norms internationally. The new government thus sought to create an international identity that reflected its own historical struggle as well as the struggle of the rest of the international community, and that also corresponded to evolving international norms with respect to human rights. Thus, South Africa's history, which drove this new identity, combined with the centrality of human rights in South African policymaking, make it a somewhat exceptional state, and exceptional states are expected to do exceptional things - and usually expect exceptional things of themselves.

South Africa's identity and its perceptions of its interests, rather than being traditionally rationalist, are domestically generated based on its history and its new understanding of itself. We thus seem to have a very strong constructivist account of South Africa's stated policies. However, this constructivist interpretation can only go so far in explaining actual behavior. We need to look at other understandings of the bases of South Africa's foreign policy to explain the disjuncture between the expectations placed on South Africa by itself and others and its actual behavior.

\section{Situationally Ordinary}

South Africa may in some ways be an exceptional state, which helps to explain its identity and interests. However, in other ways it is just another, somewhat ordinary state. From a structural, neo-realist perspective, it is a regional power with regional power interests. Even though it goes 
to great lengths to portray itself as anything but a regional hegemon - although many expect it to act as such at times (Adebajo, Adedeji, and Landsberg 2007, 27-28) - it sometimes cannot help acting as such, even though, as Adebajo et al. argue, South Africa "lacks the economic and military muscle and political legitimacy to impose its preferences on its own Southern African subregion, let alone the continent" (24). And, it has traditional security interests. While it has no reason to fear for its military security from neighboring states - none has the military strength to challenge it - it does fear for its economic security and has thus attempted to tighten its borders and exclude many of the foreign workers who had previously been at the heart of a relatively open system of regional worker migration. A concomitant domestic xenophobia flows, at least partly, from its inability to create the wealth and opportunities to dramatically improve the lives of the black majority.

South Africa's regional and economic security concerns and its position and aspirations as a regional power and a global "middle power" (Bischoff 2003; Neethling 2003, 4-6) have led it to expound and pursue two classic neo-liberal strategies - neo-liberal economic policies and multilateralism. As will be argued below, the first has had significant effects on other policies, constraining South Africa's perceived maneuvering room in pursuing some human-rightsoriented foreign policies. The second has moderated South Africa's positions as it works within multilateral settings seeking consensus rather than confrontation, and as it seeks to ensure its own economic development along neo-liberal lines. In the post-Mandela period it has expanded its participation in peacekeeping operations (Schoeman 2007, 98), thus helping to undergird its aspirations to take its place as a middle power, perhaps in the vein of Canada or Sweden (Alden and Le Pere 2004, 288). It played a significant role in developing the African Union (AU) as a stronger incarnation of the Organization of African Unity, including developing the African Peer Review Mechanism, whereby African states voluntarily undergo scrutiny of their domestic behavior, and successfully pushing for inclusion of the right to intervene militarily for humanitarian purposes by the AU in the Constitutive Act of the African Union (Landsberg 2007, 195-212). But it is not a radical vision; rather, it promotes "rules-based change and progress" (Schoeman 2007, 98) through multilateralism. It is incrementalist rather than revolutionary in orientation, as it seeks to work within existing frameworks. Given that the AU is still a conservative organization with many repressive states as members, combined with South Africa's commitment to multilateralism, it is understandable that it has not acted as a more activist state (assuming that was its wont in the first place). ${ }^{3}$

We thus see both rationalist "neos" - neo-realism and neo-liberalism (Williams 2000, 73) - reflected in the above discussion. South Africa, while perhaps exceptional in some ways, is rather ordinary in others, and even though the ANC claimed it would pursue a human-rightsbased foreign policy, South Africa has in fact pursued traditionally defined interests, even at the expense of its declared principles. At the end of this article, we revisit the theoretical question of how to explain whether and how the different logic orderings, as seen through these different descriptions of the basis of South African foreign policy, help explain South Africa's paradoxical behavior. But first, we delve deeper into the paradoxes and discontinuities of South African foreign policy.

\section{"A Betrayal of Our Noble Past"}

Thus described Archbishop Desmond Tutu, Nobel Peace Prize winner and stalwart of the antiapartheid movement, South Africa's actions (or inactions) in relation to the human-rightspromoting work of the United Nations (quoted in Neuer 2007). Tutu has not been alone in his 
disappointment at South Africa's consistent opposition to UN resolutions condemning human rights abuses and abusers around the world. A cursory overview of some of the most egregious examples should suffice to confirm Tutu's dismay. South Africa's UN-related actions take place both in New York, as a member of the UN Security Council (a position it held in 2007 and 2008, including service as chair of the Council in April 2008), and in Geneva, as one of the first 47 members of the newly created Human Rights Council (a position South Africa held from 2006 to 2010). One of the most notorious examples of South Africa siding against human rights in the Security Council came in January 2007 when, in its first vote since attaining a nonpermanent seat on the Council, South Africa joined China and Russia as the only members of the 15member body to oppose a relatively mild resolution urging Burma/Myanmar (widely considered one of the most repressive governments in the world) to free political detainees and condemning the military government's crackdown on peaceful protests. Responding to Burma/Myanmar's victory-claiming response to the vote, Tutu lamented, "the tyrannical military regime is gloating, and we sided with them" (International Herald Tribune 2007). Other noteworthy human-rightsabusing regimes that South Africa has shown little willingness to condemn are Sudan and Zimbabwe - two cases that are particularly striking in light of South Africa's view of itself as having a special role in solving African conflicts. In the Sudan case, in June 2007, the United States asked the UN Security Council to implement an arms embargo against Sudan, a request that was met with immediate opposition from Russia, China, and South Africa. Further, South Africa was at the forefront (along with Libya) of a movement to prevent the International Criminal Court from securing an arrest warrant for Omar al-Bashir, the Sudanese president, for alleged genocide in Darfur - even though it was a significant force in the creation of the ICC in the first place. More recently it has defied African Union resolutions calling on African states not to cooperate with the ICC by stating that it would arrest President Bashir if he came to South Africa (Kwinika 2010), thus lending an element of contradiction to its policies. All in all, many human rights activists would undoubtedly agree with The Economist's assessment (2008) that during its two years as a nonpermanent member of the Security Council, South Africa consistently allied itself with several authoritarian regimes to water down or block virtually every resolution pertaining to human rights abuses by states. Human Rights Watch was even more succinct, stating that South Africa's human rights reputation had been tarnished (Bogert 2008).

In terms of the South Africa's membership on the Human Rights Council, a May 2007 report by UN Watch (a Geneva-based watchdog NGO) rated all 47 members of the Council based on twenty key votes during its first year. South Africa scored at the bottom, with a grade of minus 16, tied with Cuba, Russia, China, and Saudi Arabia (UN Watch 2007a). The report concluded that "South Africa voted consistently at the UN in solidarity with the perpetrators of human rights violations instead of with the victims" (UN Watch 2007b). A study by the Democracy Coalition Project came to a similarly discouraging conclusion. Its report measured country support (or lack thereof) for credible and independent mechanisms for addressing countryspecific violations, without which the highly touted Universal Periodic Review (UPR) procedure would be closer to a farce than to the serious mechanism it was originally envisioned as. The Project's "Human Rights Council Report Card" for 2007-2008 revealed, among other things, that South Africa opposed submissions from civil society directly to the Council and instead supported the position that information provided by the states themselves should form the basis for Council review (Democracy Coalition Project 2007). This position has widely been interpreted as an attempt to make the UPR as "toothless" as possible (Neuer 2007). Some of 
South Africa's other actions on the Human Rights Council included a vote to discontinue the Council's confidential consideration of violations by Iran and Uzbekistan, despite widespread torture there, and support of a resolution to terminate all country-specific mandates. South Africa has also been seen as siding with the government of Sudan in the Council vis-à-vis the Darfur conflict, such as when, in March 2007 South Africa endorsed a weak resolution that failed to condemn Sudan for its handling of the situation in Darfur (UN Watch 2007a, 14).

South Africa's puzzling UN behavior constitutes one of the most clear-cut paradoxes of its foreign policy: the United Nations, as the institutional home of the global anti-apartheid movement, played no small part in the bringing down of the apartheid system. However, when given the opportunity to support bringing similar UN pressure to bear on other human-rightsabusing regimes, South Africa has refused to do so.

While South Africa's behavior in the UN obviously reveals that rhetoric would not always be matched by actions, by far the best-known chasm between expectations and deeds has been the government's unwillingness to publicly confront Zimbabwe's Robert Mugabe or to condemn the gross violations of human rights committed by his government and followers. While South Africa has been reluctant to confront Mugabe for several years, its unwillingness to condemn the Zimbabwean government for its human rights abuses was particularly glaring in the period surrounding the March 2008 general election, which was widely deemed by the international community to have been neither free nor fair, in large part due to violent voter intimidation attributed mainly to Mugabe supporters. South Africa used its position as president of the UN Security Council in April 2008 to prevent sending a fact-finding mission or special envoy to investigate post-election violence; nor would it allow the Council to debate the worsening situation. Indeed, during the month that South Africa held the Security Council presidency-i.e., the month in which post-election violence in Zimbabwe soared-Thabo Mbeki declared that there was "no crisis" in Zimbabwe. Finally, in June 2008, in the midst of increasing violence in the days preceding a runoff election, the Security Council issued a one-page statement (which was watered down at the insistence of South Africa, Russia and China) calling on the government of Zimbabwe to permit opposition rallies and to free political prisoners. However, when a United States-sponsored resolution calling for sanctions (primarily in the form of an arms embargo and targeted travel and financial sanctions against fourteen people) against Zimbabwe was introduced in July 2008 (in the aftermath of a runoff election deemed almost universally to be illegitimate), it was defeated by a rare double veto by China and Russia - which found themselves in the company of South Africa, Libya, and Vietnam in voting against sanctions. (South Africa had also refused to condemn the election-related brutality in the Human Rights Council in March 2007).

In December 2008, acting South African president Kgalema Motlanthe refused to join other world leaders, including Condoleeza Rice of the United States, Nicolas Sarkozy of France, and Seretse Ian Khama of Botswana, in their calls for Mugabe to step down in the context of a growing humanitarian crisis exemplified by an outbreak of cholera, which had affected close to 40,000 people by January 2009, killing almost 2,000 of them. The paradox is clear: South African leaders, once victims of a brutal and oppressive regime, are now implicitly condoning brutality and oppression of Africans, in the country directly to its north. South Africa's refusal to condemn Mugabe is all the more striking because in the early 1980s a newly independent Zimbabwe used its position as a nonpermanent Security Council member to vote to condemn the apartheid regime (Wines 2007). Noting the impact that South Africa's tacit support of Mugabe has had on its reputation, The Economist (2008) opined that "among the international human- 
rights fraternity, post-apartheid South Africa — the democratic, multicultural 'rainbow nation' forged by Nelson Mandela - is once again regarded as something of a pariah," and it accused Pretoria of aligning with "some of the world's least savoury regimes."

South Africa's pro-Zimbabwe policy has resulted directly in a third apparent paradox of South African foreign policy: its treatment of refugees. As Zimbabwe approaches the status of a failed state, more than three million Zimbabweans are estimated to have fled in the past few years - almost half of them to South Africa, where they face a profoundly unwelcoming South African immigration system that, more often than not, treats all refugees as voluntary economic migrants and summarily deports them without determining the validity of their asylum claims. Human Rights Watch has documented the often-unlawful deportation of more than 250,000 Zimbabweans a year, revealing that South Africa engages in refoulement, thereby violating the most basic principle of refugee law: the right not to be forcibly returned to persecution (Human Rights Watch 2008, 1). Again, the policy paradox is clear: the ANC government, many of whose leaders received refuge in neighboring countries while fleeing the abusive apartheid regime, are now regularly implementing human-rights-abusing refugee policies themselves. As Nathan notes $(2005,371)$, "the treatment of African refugees and asylum seekers is shamefully reminiscent of the apartheid era."

\section{Making Sense of the Contradictions}

Having addressed the first question of why so much was expected of South Africa and examined South Africa's actual foreign policy behavior, we now turn to the question of why these expectations have not been met. We identify three explanations of South Africa's foreign policies under the Mandela and Mbeki regimes. As we will demonstrate, these explanations correspond to the various ordering logics outlined above.

\section{Competing Ideologies}

Since South Africa's policies towards Zimbabwe (especially Mbeki's "quiet diplomacy") have been so controversial, it is perhaps not surprising that they have been the focus of many scholarly writings. Laurie Nathan concentrates primarily on Mbeki's foreign policy priorities, which he says emphasize Afrocentrism; a principled commitment to democracy and respect for human rights; a holistic approach to security in which the primary threats to security are seen not as military but as bad governance and underdevelopment; a commitment to pacific forms of conflict resolution, especially through mediation; and the promotion of multilateralism in the international system. These themes clearly match South Africa's stated commitment to placing human rights at the forefront of foreign policy. The discontinuities arise, however, Nathan argues, because these five pillars are informed by, and are sometimes in conflict with, Mbeki's own ideological commitments. "In international affairs," Nathan notes, "Mbeki is as much an ideologue as a pragmatist, his outlook rooted in three paradigms: democratic; Africanist; and anti-imperialist." Herein lies the rub-sometimes Mbeki's ideologies complement, and indeed shore up, his foreign policy priorities; at other times, however, the two (foreign policy goals and ideology) stand at cross purposes with each other. Specifically, Nathan notes $(2005,363)$, "the Africanist and anti-imperialist paradigms, which include a visceral anger at historical and contemporary manifestations of imperialism and racism, are seldom if ever in conflict with each other, but both are occasionally in conflict with the democratic paradigms. In these cases, it is usually the democratic position that gives way." 
While Nathan does not refer to it this way, Mbeki's personal ideology has often been summed up as the "African Renaissance," which one scholar has referred to as "the defining policy concept of Thabo Mbeki's presidential administration" (Jo-Ansie van Wyk, quoted in Neethling 2003, 8). The concept has been defined in various ways, and different scholars highlight different aspects and implications of the set of ideas embodied in the concept. Bischoff (2003, 199) defines the African Renaissance as resting on three pillars: "the mobilisation of the African people to take their destiny in their own hands and stand up for clean and purposive government; the establishment of political democracy, respect for human rights and good governance; a clear program of economic regeneration to help reposition Africa in the world economy and at the same time bring about a new more equitable world order." Mbeki himself (1998) described the philosophy as being in part anti-colonial; in part an attempt to assert Africa's capacity to solve its own problems; and in part a call for the restoration of the dignity of Africans. On other occasions, he has emphasized good governance (defined as civilian rather than military governments, multiparty rather than one-party states, and the adoption of the African Charter of Human and People's Rights), and end to poverty and disease (especially through economic development and under the leadership of the Southern African Development Community [SADC]), and cooperation against violence (through regional peacekeeping and security arrangements and through regional cooperation to combat crime).

It is clear that the seeds of potential contradiction are contained in Mbeki's philosophy: the African Renaissance is simultaneously anti-imperial and anti-colonial (and might thus be proMugabe) as well as supportive of democratic good governance (and might thus be anti-Mugabe). The African Renaissance is pro-Africanist (and might thus predict a willingness to allow suffering African refugees to enter South Africa) but also pro-development (which might predict a policy of being unwelcoming to people who could be viewed as economic migrants).

Applying this set of contradictions to South Africa's approach to Zimbabwe, one of Mugabe's core interests - land reform - has resulted in severe human rights abuses. Mugabe has consistently framed the issue in terms of righting colonial-era wrongs, and this clearly resonates with Mbeki's anti-imperial ideology. However, Mbeki endorsed the principle "without questioning the illegal and violent manner in which it was done," thus confirming Nathan's sense (2005) that Mbeki's anti-imperialist ideology trumps his commitment to human rights and the rule of law. James Barber $(2005,1093)$ echoes Nathan's analysis, noting that in 2003 Mbeki attributed Zimbabwe's problems not to bad governance on the part of Mugabe but rather to "the legacy of colonialism and white dominance." Mbeki consolidated his anti-colonial/anti-imperial credentials by accusing prime ministers Tony Blair of the United Kingdom and John Howard of Australia of being racist, claiming that their proposal at a 2003 Commonwealth meeting to ostracize Mugabe was "inspired by notions of white supremacy" (quoted in Barber 2005, 1093). Like Nathan, Barber chalks up Mbeki's support for Zimbabwe to the aligning of two of his three ideologies: anti-colonialism and pro-Africanism. Barber sees these ideologies playing out in three ways. First, Mbeki consistently opposed Western interference in Zimbabwe. Second, his support for Mugabe reflects his respect for the Zimbabwean leader's stature as a hero of the liberation struggle, the last of the first generation of African leaders still in power. As such, Mugabe holds for many, Mbeki included, "a special place in the liberation saga;" he is, for them, “a living legend." Finally, Mugabe's stated goal of returning land to indigenous blacks - its rightful owners - fit well into Mbeki's anti-colonial worldview (Barber 2005, 1094). In light of all of this, the third strand of Mbeki's ideological outlook - support for democracy — was bound to be overlooked. South Africa's accomodationist policies towards Zimbabwe are, in short, a far 
cry from the ANC Working Group statement (1994) that "Human rights concerns will also influence our bilateral relations. In this we shall not be selective nor, indeed, will we be afraid to raise human rights violations with countries where our own and other interests might be negatively affected. South Africa's experience, we believe, shows how damaging policy can be when issues of principle are sacrificed to economic and political expediency."

We can also make sense of South Africa's UN actions by viewing them in the light of conflicting ideologies. The promotion of multilateralism as a means for maintaining global order and addressing global problems was a stated focus of Mbeki's presidency, explaining South Africa's desire to play an important role in both international multilateral regimes (as onetime chair of UN Conference on Trade and Development, the UN Commission of Human Rights, and the Non-Aligned Movement, for example) and continental multilateral regimes such as the SADC, the New Partnership for Africa's Development, and the African Union, for example. This focus also explains South Africa's stated goal of playing the role of reformer in the international financial institutions and the United Nations, especially the Security Council. However, having achieved its goal of becoming a Security Council member, the pro-African and anti-colonial values seem to have taken over. Neuer (2007) claims that South Africa dismissed the Council vote condemning Burma as yet another campaign by the wealthy North. Human Rights Watch claims that South Africa views the International Criminal Court as an anti-African institution (Bogert 2008) (although its initial strong support for the Court, along with its recent defiant tone against the official AU position when it declared it would arrest Bashir should he come to South Africa, problematize such a black and white interpretation). One American diplomat explains South Africa's performance in its two years on the Security Council thus: "What you have here is the continuing, ongoing tussle over whether the A.N.C. is still a protest movement or the governing party of a responsible member of the international community. ... They're reflexively against anything we're for-we in the States, we and the British, we in the North. It's more Chinese than the Chinese" (quoted in Wines 2007).

Graham Evans $(1999,623)$ offers a different perspective on competing ideologies as an explanation for contradictory policies. Evans examines the history of the ANC's thinking on international relations and sees three distinct phases. From 1912 (the time of its founding) through 1960 (the time of its banning), the ANC's international thinking was akin to today's liberal internationalism. This was succeeded by the period from 1960-1993 (the time of its exile), when the ANC's foreign policy can be described as socialist. Finally, from 1993 on, the ANC's foreign policy ideology was in Evans' view pragmatist. Each change in ideological orientation, Evans argues, occurred in response to external stimuli $(1999,623)$. The crux of Evans' argument is this: South Africa's apparently contradictory foreign policy today reflects the fact that it contains elements drawn from all three historical ideological phases. Specifically, he notes:

The alleged confusion in post-apartheid South Africa as to the nature of foreign policy and the kinds of roles the state should adopt in the region and in the wider world is in no small part attributable to the pull/push effects of this competing triad of theoretical perspectives and the lack of consensus the tensions between them have generated within the ranks of the ruling party. The result is that foreign policy is often argued out within a context of competing and often mutually exclusive perspectives (623).

In other words, one policy choice might reflect one historical perspective, while another choice might reflect a different perspective. Applying Evans' explanations, one can see for example, that South Africa's policy of preventing a flood of supposed economic migrants from crossing its 
border is an economically pragmatic decision for a country facing an unemployment rate of close to $25 \%$. However, this policy towards migrants, many of whom are African refugees, stands in direct contradiction to the socialist-informed demand that policy ought to be ethical, solidarist, and Afrocentric. Likewise, Pretoria's demands for UN reform and its active quest for a larger role in the UN Security Council reflects elements of a historic commitment to liberal internationalism. However, once on the Security Council, its policies appeared driven instead by pro-African and anti-Western socialism. These competing, often mutually exclusive, policies that derive from the developmental phases of ANC thinking are an indication to Evans $(1999,623)$ that "South Africa's post-Cold War and post-apartheid identity and its conception of where its national interests lie, is still in the process of gestation." For Evans, then, the observed gap between rhetoric and reality can best be explained as a function of historical tensions that continue to be played out on the world stage today: "the main division [has been] between second-phase populists and ideologues and third-phase pragmatists and neo-liberals. This ongoing debate has served to frustrate the development of a coherent world-view and the accusations of vacillation, ineffectualness and 'ad hoc-ery' that have been leveled at the new South Africa's foreign policy" (624).

We thus see a constructivist logic of appropriateness operating, as South Africa's ideologies and ideas about itself come to the fore in defining South African policies. However, it is constructivism with an argumentative twist, since there is an ongoing debate within and between ideologies. As South Africa "argues" with itself over which vision or version or element of the African Renaissance to prioritize, one sees a somewhat incoherent answer, with the democracy/human rights element winning at times, but the anti-imperial/Afrocentric elements prevailing more often.

\section{Continental Constraints}

The second factor that explains discontinuities in South Africa's recent foreign policy behavior is closely related to the first one, especially in relation to Mbeki's African Renaissance ideology. One of the ideas implicit in the African Renaissance is African unity. If Africans are resolved to address their own problems, free from former colonial - and especially Western - influence, then one approach is a closing of ranks, a circling of wagons of sorts, among African countries. To the extent that this has happened, African countries have by and large said to the West, "yes, we have our problems, but they are our problems. You do not have the right to criticize us, nor can you solve them for us." Mbeki himself linked the ideas of African unity and African selfsufficiency in his speech in Durban at the launching of the African Union in 2002, saying:

Imperialism and colonialism had sought to own and control Africa permanently, from Cape to Cairo. African pride and courage ensured that Africans own and control Africa permanently, from Cape to Cairo. . . By forming the Union, the peoples of our continent have made the unequivocal statement that Africa must unite! We as Africans have a common and a shared destiny! Together, we must redefine this destiny for a better life for all the people of this continent (South African Department of Foreign Affairs 2002).

By itself, the concept of African unity need not be the engine of contradictory foreign policy for South Africa. However, contradictions have arisen when the South African government has opted to choose unity with authoritarian human-rights abusing regimes in the name of African unity. The prioritizing of solidarity politics over rights-based politics on a continent rife with anti-democratic leaders represents what we term a continental constraint for South Africa, one 
that is part of the explanation of the gap between rhetoric and reality in its foreign policy. Other scholars who have noted a sense of constraint inherent in African solidarist politics include Alden and le Pere (2004), who claim, for example, that South Africa's ability to promote ethical values has been made difficult because of the ambivalence towards democracy and human rights among key SADC leaders. Although the rhetoric of democracy and human rights featured prominently in the immediate post-apartheid foreign policy debates, they argue, the need to work within SADC, despite that organization's formal commitment to these issues, "has tended to circumscribe substantive action in support of these values. This in turn has had a direct effect upon the selection of tools available to policy makers in Pretoria, limiting them to public statements through SADC that emphasised organizational cohesion [i.e., solidarity] over expressions of concern or condemnation of actions by fellow members" (290). ${ }^{4}$

In relation to the issue areas explored above, Nathan $(2005,367)$ makes the connection between South Africa's (and SADC's) desire for unity and its concomitant impact on its policies in its relationship with Zimbabwe. He notes:

They [the SADC] are determined to maintain a posture of unity and solidarity.

Forged in the heat of the struggles against colonialism and apartheid, this posture militates against public criticism of each other. The imperative of solidarity is greatest when foreign powers raise concerns that are perceived as reflecting an imperialist agenda. These dynamics have been evident in extremis in the case of Zimbabwe. Here, far from remaining silent, SADC has repeatedly expressed solidarity with Harare and trivialized human rights concerns.

Alden and le Pere $(2004,283)$ similarly note that South Africa's puzzling foreign policy choices can be explained in part by what they refer to as its paradoxical legacy of the apartheid state and the liberation movement. They argue that "the new South Africa faced contradictory tensions in developing an activist role in foreign policy premised upon a belief in the compatibility of human rights norms, solidarity politics, and its own development needs." In other words, South Africa felt the tension of wanting to project a moral foreign policy because of its legacy of apartheid, but also wanting to stand in solidarity with states that are not always human rights supporters but that supported the ANC when it was a liberation movement. Again, one gets a sense of a value hierarchy-African solidarity trumps human rights and democracy:

Even in those crises - Zimbabwe in particular-where South African interests were most directly effected [sic] and leverage was assumed to be considerable, the range of actions available that would not exact costs in terms of SADC unity. . .. turned out to be far fewer than policy makers in Pretoria had anticipated. By adopting the 'quiet diplomacy' approach towards Zimbabwe, Mbeki had hoped to underscore the limitations of South Africa's willingness to overtly challenge the non-interventionist norm in SADC. . (Alden and le Pere 2004, 290).

In truth, Bischoff $(2003,191)$ concludes, the idea that an African renaissance would result in a "mass crusade against authoritarian and corrupt ruling leaders" turned out to be "more promise than policy," as human rights issues have consistently been "subsumed under the need for states inclusively to seek unity of purpose."

One reason South Africa has generally been unable to overcome the continental constraint of African unity, even if it wished to, has to do with its own role-both historical and contemporary - on the continent. The government has had to be wary of being seen as being too assertive because of regional fears of domination, especially in light of its history of regional destabilization in the 1990s. As Alden and le Pere $(2004,289)$ note, "Complicating South 
Africa's engagement with the region is its own history of intervention in regional affairs, much of which centred upon destabilising regional co-operation, and a contemporary desire to undo that legacy through active consultation with member states." South Africa's African partners continue to maintain a fair amount of skepticism about its aspirations for continental leadership. Mbeki in particular was regarded with suspicion by other African leaders, privately referred to as the "George Bush of Africa," "leading the most powerful nation in the neighborhood and using his financial and military muscle to further his own agenda" (Neethling 2003, 15). Thus, South Africa's history as a regional bully combined with its potential of being a modern-day one have, in many ways, forced the government to err on the side of unity rather than condemnation when faced with human rights abuses in its backyard. Bischoff $(2003,194)$ sums up this dilemma well:

There are African governments that would prefer South Africa not to play a leadership role. Consequently, South Africa fears the political fallout from not acting collectively. Political opponents fearing their own displacement in the politics of the continent and leaders used to having things their own way in settings where 'brother does not attack brother' are loath to award the role of a diplomatic broker to Pretoria.

Again, we see an argument between different elements of the African Renaissance ideology and the legacy of South Africa's past. Yet, this argument is also tinged by more consequentialist concerns. To maintain its power, it needs to been seen as not overly powerful and domineering, and thus has to acquiesce to less human rights-supporting currents in Africa to reinforce its African unity credentials. Thus, both ideational arguments and material concerns are operating concurrently, although the latter frequently appear to hold greater sway and thus constrains the possible outcomes of the ideational arguments.

\section{Global Constraints}

Perhaps a more forgiving explanation for South Africa's inability to live up to its professed ideals is that the same global conditions that facilitated apartheid's demise also constrain South Africa's foreign policy choices. This is especially true in relation to so-called second generation social and economic rights. One of the core tenets of Mbeki's African Renaissance was a commitment to global redistribution of wealth, with a special emphasis on economic development in Africa. Along with competing ideologies and continental constraints, this points to a third tension, between South Africa's desire to play an activist role in pushing human rights norms globally and its need to ensure its own economic development. Moreover, South Africawhose economy was in decline by apartheid's end - had the great misfortune of having to learn to compete in an increasingly globalizing world. In other words, as Alden and le Pere (2004, 286) note, "the ANC's idealistic leanings and the realist inclinations of a globalised world brought into stark relief a range of tensions and contradictory impulses in implementing foreign policy." Once again, faced with choices between competing values, South Africa sacrificed its commitment to human rights to that of economic development, such that - as Alden and le Pere put it, "the carefully crafted ethical dimension of foreign policy was supplanted" (286).

Why is there tension between economic development and ethical foreign policy? Critics accuse South Africa, and Mbeki in particular, of abandoning its socialist redistributive legacy, one that hearkened back to the 1955 Freedom Charter, in favor of a neo-liberal emphasis on foreign-investment-led growth and open markets (reflected in its economic and fiscal policy known as GEAR — Growth, Employment and Redistribution Strategy — of 1996). Thus, while the government made noises about fighting the effects of unfettered capitalism, in reality its 
economic policy more closely resembled a neo-liberal cocktail (Bischoff 2003, 189). Peter Vale and Ian Taylor $(1999,631)$ refer to these critics when they note that "though, it is true, South Africa postures a reformist platform that argues for a safeguard against the most negative effects of globalization, the ANC has most certainly - to the vocal disappointment of its partners in the tripartite alliance and large segments of its traditional constituency-bought into the neoliberalist discourse." A kinder interpretation is that Mbeki's hands were tied. For many, Mbeki's commitment to redistributive justice was real. He was a key advocate in the global campaign for unconditional debt relief to Highly Indebted Poor Countries, 33 of which are in Africa. Bischoff (2003, 185-86) argues that Mbeki believed that globalization could incorporate economic rights for states, and that there should be a "compensatory movement to globalisation, one that through conscious interventions could correct the inability of the market to address issues of peace, democracy, health, and prosperity." Mbeki was forced to abandon this attempt to pursue both economic rights and economic growth, however. As a result, Paul Williams argues (2001, 73), the government was compelled by the global economic climate to adopt "an eclectic synthesis of neo-realist and neo-liberal principles." As Alden and le Pere $(2004,288)$ note, the South African government will be judged by two criteria: its ability to bring regional peace and security and its ability to generate wealth. In both cases, they argue, the government learned quickly that "rectitude and idealist leanings were difficult to sustain in a world where realpolitik and champions of free market held sway." They, too, believe that South Africa had no choice but to sacrifice socialism in favor of pragmatism. In reference to Mbeki's dilemma, they note: "a world-view driven by ambition to do good and a belief that the coin of idealism still holds value in an increasingly Darwinian world suggests an absolutism that might be difficult to hammer out on a pragmatic anvil of means and ends" (289).

A different aspect of the global constraints explanation is highlighted by Bischoff (2003, 186), who argues that South Africa's ability to serve as a global leader capable of exercising leadership on such "middle power" issues as debt relief, nuclear nonproliferation, and other human-rights-related issues, was seriously curtailed by a sharp return to a realist world in the aftermath of the September 11, 2001 attacks on the United States and the ensuing global war on terror. This became even more true after the 2003 U.S. invasion of Iraq. The drastically changed global political environment, with its renewed focus on issues of "hard power," meant that "soft power" issues that are best championed by middle power countries such as South Africa took an immediate backseat. Bischoff $(2003,186)$ concludes: "the current international system is characterized by lurches towards American-led unilateralism and the diminution of multilateralism. This weakening of multilateralism reduces South Africa's potential for playing the role of facilitator and bold reformer." South Africa's role as a transformative power in world affairs was pulled out from under it by forces beyond its control.

While South Africa's post-apartheid leaders may have wanted to pursue an ethical, human rights supporting foreign policy, materialist considerations got in the way. The possible paths for South African economic development were constrained by neo-liberal globalization, and the hyper-realist pots-9/11 world was not conducive to such an ethical foreign policy. Thus, global realities constrained possible directions South African foreign policy could take.

\section{Theorizing Post-apartheid Foreign Policy}

This complex picture of South African foreign policy returns us to the theoretical framework outlined earlier. Can the four ordering logics we discussed shed light on the paradoxes which appear in South Africa's policies over the last 15 years? Table 1 indicates the behavior predicted 
by the various ordering logics as well as actual behavior on the part of South Africa. As we have discussed, there has been a general expectation that South Africa would put human rights front and center in its foreign policy, an expectation fostered by numerous statements by the government of South Africa and various South African leaders. Yet, at first glance, we seem to be significantly let down by logic-of-appropriateness explanations. South Africa has been a significant player in developing norms and institutions that would further the cause of human rights. At the African Union it was a driving force behind the peer review mechanism and the policy on humanitarian intervention, and it also sought and won a seat on the UN Human Rights Council. Yet it failed to follow through on these promising beginnings, blocking concrete action in these new institutions. Thus, while, the logic of appropriateness might explain South Africa's initial push to develop human rights institutions, it fails to explain why it did not use these institutions to their potential and, in fact, impeded their effectiveness, as well as violating a key human rights norm, refugees' right not to be forcibly returned to a country where they face persecution (nonrefoulement).

Logic-of-consequences arguments might, at least superficially, shed better light on South Africa's foreign policy conduct. The neo-realist wing of rationalist arguments might predict that it would seek out important positions in international bodies (which it has), not to pursue human rights policies but rather to pursue prestige and power. Neo-liberal rationalism would also predict a state's pursuit of multilateralism, not necessarily only for its own sake but rather to ensure the regional and global stability that would be in its interest. Yet, again South Africa did not always engage in predicted behavior as it blocked action aimed at addressing crises that affect it directly (such as Zimbabwe) and indirectly (such as Darfur). At the same time, it has taken the lead in attempting to mediate other crises, such as in the Democratic Republic of Congo. One area where it has engaged in expected rationalist behavior is in its pursuit of neo-liberal economic policies which, among other things, has led to maltreatment of refugees and asylum seekers, in direct contradiction with its international obligations (as well as in contradiction with the debt it owes Zimbabwe and other African countries for sheltering those fleeing the apartheid regime). Thus, both continental and global constrains constrained its policy choices.

To more fully understand the paradoxes of South African foreign policy, however, we must look to explanations deriving from the logic of arguing, which may shed some light on the competing norms and interests found in post-apartheid foreign policy. Nowhere is an internal "argument" more evident than in the ideas embedded in the African Renaissance - support for democracy, Afrocentrism, and anti-imperialism. While the first element was clearly evident in the rhetoric and reality of post-apartheid South Africa (witness Mandela's failed attempt to put pressure on Nigeria), under Mbeki, the other two elements moved to the fore. In the case of Zimbabwe, a focus on African solutions to African problems and the instinct to support a fellow revolutionary who had given great support to the anti-apartheid struggle led to a situation where two normative elements of the new South African ideology shoved the third - and some might argue, more foundational - aside. In this particular argument, democracy - and ethical foreign policy - was eclipsed by two other very powerful normative currents. With regard to its overall performance internationally in supporting human rights, again human rights lost out to Afrocentrism and anti-imperialism as South Africa refused to use its time on the UN Security Council to condemn a variety of human rights abuses around the world. Acting more like a protest and solidarist movement than a governing party, the ANC allowed the "anti" elements of the African Renaissance (anti-imperialism, anti-Westernism, etc.) to overcome the more positive elements. In the AU, while originally supporting very significant human-rights-protecting ideas, such as 
the peer review mechanism and humanitarian intervention, the African solidarity elements prevented it from being more vocal in condemning human-rights-abusing governments in Zimbabwe and elsewhere. And paradoxically, South Africa has, at times, supported AU policy on the ICC and President Bashir, while defying it at other times. Thus, the competing ideologies embedded within the African Renaissance helped (along with domestic ideas) to create ethical expectations for South African foreign policy while also pulling in the opposite direction, frequently leading to what many would see as disappointing policy outcomes.

While each of the aforementioned logics may explain parts of the South African foreign policy paradoxes, none can explain everything. We thus move to the last ordering logic outlined in Table 1 - concurrence. A mixture of both normative and traditional self-interest forces seems to have played out in the development of foreign policy, pushing in different directions. As we have seen, post-apartheid South Africa seemed reborn as a human rights norm entrepreneur, as evidence by its actions in connection with the AU and Nigeria, for example. Yet, more traditional interests, in particular economic ones, as well as a desire to take its place as a global middle power (without threatening its neighbors with perceptions of hegemony) led it to moderate some of its positions and take other actions, such as those relating to refugees and other migrants. Normative positions, including Afrocentrism and anti-imperialism pointed, in a number of instances, in the same direction as rationalist theories might suggest - i.e., away from human rights. How does this fit within our framework? Does it indicate concurrence with a twist - norms and interests acting together, against other norms? We should not be surprised that this may happen at times. This highlights a significant issue with regard to our theorizing and, in particular, the framing of state action within well-defined metatheoretical perspectives. Real life is always more messy than the ideal types we create to describe and explain real life. However, we hope our discussion sheds some light on the apparent paradoxes of South African postapartheid foreign policy, highlighting a continuing struggle between acting like a "normal" state and an exceptional one, as well as a struggle to define the terms of that exceptionalism.

\section{Conclusion}

The end of apartheid and the coming into power of the ANC in South Africa represented one of the most important victories for the modern global human rights movement. The way the victory occurred was exceptional and this history seemed to presage exceptional things for the postapartheid South African state. These expectations were further raised by South African leaders themselves when they declared that South Africa would use its newfound international status to support human rights around the world in the same way that the world had supported the human rights struggles of the black majority in South Africa. Such hopes were quickly dashed, however, as time and again South Africa disappointed many around the world (and, one might argue, itself) by failing to follow through on these affirmative commitments.

In the post-apartheid era South Africa has struggled to define its identity and its interests, arguing internally about its priorities and vision - about whether to live up to Nelson Mandela's and the world's expectations of putting human rights at the center of its foreign policy, and thus to act as an exceptional state, or whether to act as a more ordinary state and pursue policies based on traditional state interests. More fundamentally perhaps, South Africa has been engaged in a struggle not between ideas and interests (although this has certainly played a role) but rather between competing ideas. Very quickly the norms embodied in Mbeki's African Renaissance came into conflict with each other, with African unity and anti-imperialism (reflecting their roots in the anti-apartheid struggle) frequently winning out over democracy and human rights (which 
are similarly rooted in the anti-apartheid struggle). In theoretical terms, while there has obviously been a conflict between ideas and interests, the question of which ideas have been seen as most salient - which appropriate behavior and responsibility to whom - has dominated South Africa's quest to define itself. Is it exceptional or is it ordinary? Does it identify with Western liberal states or is it "African" and anti-imperialist at its core? Can it be both, as Mbeki long implied it could? Such questions will likely continue to bedevil South Africa even as the world continues to expect it to do great things. While they may no longer be surprised, observers may well continue to be dismayed, if South Africa stubbornly - and perhaps understandably - continues to defy expectations created for it and by it. 
TABLE 1: Competing Theoretical Explanations of South African Foreign Policy

\begin{tabular}{|c|c|c|}
\hline Ordering Logic & Expected Policies & Actual Policies \\
\hline Logic of Consequences & $\begin{array}{l}\text { Neo-realist/Neo-liberal, with a focus on } \\
\text { economic development, regional and global } \\
\text { power, and multilateralism }\end{array}$ & $\begin{array}{l}\text { Restriction/return of refugees to protect } \\
\text { economic development; } \\
\text { Participation in multilateral bodies, but } \\
\text { not leadership }\end{array}$ \\
\hline Logic of Appropriateness & $\begin{array}{l}\text { Human rights placed at core of foreign policy, } \\
\text { such as exercise of regional/global leadership, } \\
\text { condemnation of human-rights-abusing } \\
\text { regimes, support for robust human rights } \\
\text { action, and admission of refugees }\end{array}$ & $\begin{array}{l}\text { Development of African Union peer } \\
\text { review mechanism and policy on } \\
\text { humanitarian intervention; } \\
\text { Sought membership on Human Rights } \\
\text { Council; } \\
\text { Support for African Union and UN } \\
\text { generally, but no trailblazing leadership }\end{array}$ \\
\hline Logic of Arguing & $\begin{array}{l}\text { Those consistent with African Renaissance } \\
\text { tenets of support for democracy, } \\
\text { Afrocentrism, and anti-imperialism }\end{array}$ & $\begin{array}{l}\text { Support for African rights abusing } \\
\text { leaders; } \\
\text { Refusal to condemn third world leaders } \\
\text { at UN (on Security Council and } \\
\text { Human Rights Commission); } \\
\text { paradoxical policy on the ICC and } \\
\text { Bashir }\end{array}$ \\
\hline Concurrent logics & $\begin{array}{l}\text { A mix of policies, with no overarching logic } \\
\text { or consistency }\end{array}$ & $\begin{array}{l}\text { An initial push for human rights, then } \\
\text { pulling away; } \\
\text { Norm/institution building (African } \\
\text { Union, Human Rights Commission), } \\
\text { but no follow through; } \\
\text { Affirmative statements but no policy }\end{array}$ \\
\hline
\end{tabular}




\section{References}

ADEBAJO, Adekeye, ADEDEJI, Adebayo, and LANDSBERG, Chris. (2007) Introduction, in South Africa in Africa: The Post-apartheid Decade, Adekeye Adebajo, Adebayo Adedeji, and Chris Landsberg (eds.) (University of KwaZulu-Natal Press), 17-39.

ALDEN, Chris, and LE PERE, Garth. (2004) South Africa's Post-Apartheid Foreign Policy: From Reconciliation to Ambiguity, in Review of African Political Economy, 31(100), 283-297.

ANC WORKING GROUP. (1994) Views from the Practitioners: Foreign Policy in a New Democratic South Africa, in From Pariah to Participant: South Africa's Evolving Foreign Relations, 1990-1994, Greg Mills (ed.) (Johannesburg: South Africa Institute of International Affairs).

BARBER, James. (2005) The New South Africa's Foreign Policy: Principles and Practice, in International Affairs, 81(5), 1079-1096.

BISCHOFF, Paul-Henri. (2003) External and Domestic Sources of Foreign Policy Ambiguity: South African Foreign Policy and the Projection of Pluralist Middle Power, in Politikon, 30(2), 183-201.

BOGERT, Carroll. (2008) South Africa's Human Rights Reputation Tarnished, Human Rights Watch, (September 7, 2008). [Online]. Available:

http://www.hrw.org/en/news/2008/09/06/south-africas-human-rights-reputation-tarnished?print.

DEMOCRACY COALITION PROJECT. (2007) Human Rights Council Report Card:

Government Positions on Key Issues, 2007-2008” Democracy Coalition Project (October 2007). [Online]. Available:

http://www.demcoalition.org/pdf/HRC\%20Table\%20of\%20Indicators \%20for\%20Year\%20One \%20-\%20Full\%20Chart.pdf.

EVANS, Graham. (1999) South Africa's Foreign Policy after Mandela: Mbeki and His Concept of an African Renaissance, in The Round Table, (352), 621-628.

FINNEMORE, Martha. (1996) National Interests in International Society (Ithaca: Cornell University Press).

GLASER, Charles L. (1994) Realists as Optimists: Cooperation as Self-help, in International Security, 19(3), 50-90.

HUMAN RIGHTS WATCH. (2008) Neighbors in Need: Zimbabweans Seeking Refuge in South Africa (New York: Human Rights Watch).

INTERNATIONAL HERALD TRIBUNE. (2007) Desmond Tutu 'deeply disappointed' with South Africa's vote against U.N. Security Council resolution on Myanmar. International Herald 
Tribune, January 21, 2007. [Online]. Available:

http://www.iht.com/articles/ap/2007/01/21/africa/AF-GEN-South-Africa-Tutu-Myanmar.php.

KEOHANE, Robert (ed.) (1986) Neorealism and Its Critics (New York: Columbia University Press).

KRASNER, Stephen. (1999) Sovereignty: Organized Hypocrisy (Princeton: Princeton University Press).

KWINIKA, Savious. (2010) Sudan President Bashir, accused of war crimes, would be arrest in South Africa, says ANC. Christian Science Monitor, July 28, 2010. [Online]. Available: http://www.csmonitor.com/World/Africa/Africa-Monitor/2010/0728/Sudan-President-Bashiraccused-of-war-crimes-would-be-arrested-in-South-Africa-says-ANC.

LANDSBERG, Chris. (2007) South Africa and the making of the African Union and NEPAD: Mbeki's 'progressive African Agenda' in South Africa in Africa: The Post-apartheid Decade, Adekeye Adebajo, Adebayo Adedeji, and Chris Landsberg (eds.) (University of KwaZulu-Natal Press).

MANDELA, Nelson. (1993) South Africa's Future Foreign Policy, in Foreign Affairs, 72(5), 8697.

MARCH , James G., and OLSEN, Johan P. (1998) The Institutional Dynamics of International Political Orders, in International Organization, 52(4), 943-970.

MBEKI, Thabo. (1998) The African Renaissance, South Africa, and the World. Speech given at the United Nations University in Tokyo on April 9, 1998. [Online]. Available: http://www.unu.edu/unupress/mbeki.html.

MILLS, Kurt. (2009) Vacillating on Darfur: Responsibility to Protect, to Prosecute, or to Feed?, in Global Responsibility to Protect, 1(October 2009), 532-559.

MILLS, Kurt, and LOTT, Anthony. (2007) From Rome to Darfur: Norms and Interests in U.S. Policy Toward the International Criminal Court, in Journal of Human Rights, 6(4), 497-521.

NATHAN, Laurie. (2005) Consistency and Inconsistencies in South African Foreign Policy, in International Affairs, 81(2), 361-372.

NEETHLING, Theo. (2003) South Africa's Evolving Role in Peacekeeping: National Interest and International Responsibilities, in Journal of Military and Strategic Studies, 6(2).

NEL, Philip, TAYLOR, Ian, and VAN DER WESTHUIZEN, Janis. (2000). Multilateralism in South Africa's Foreign Policy: The Search for a Critical Rationale, in Global Governance, 6(1), 43-60. 
NEUER, Hillel. (2007) South Africa at the UN: Your Freedom and Mine, in Sunday Times of South Africa (December 9, 2007). Reprinted by UN Watch. [Online]. Available: http://blog.unwatch.org/?p=78.

RISSE, Thomas. (2000) “Let's Argue!”: Communicative Action in World Politics, in International Organization, 54(1), 1-39.

RISSE, Thomas. (2002) Constructivism and International Institutions: Toward Conversations Across Paradigms, in Political Science: The State of the Discipline, Ira Katznelson and Helen V. Milner (eds.) (New York: Norton): 597-623.

SCHOEMAN, Maxi (2007) South Africa in Africa: behemoth, hegemon, partner or just another kid on the block, in South Africa in Africa: The Post-apartheid Decade, Adekeye Adebajo, Adebayo Adedeji, and Chris Landsberg (eds.) (University of KwaZulu-Natal Press).

SCOTT, Gary L., REYNOLDS, Geoffrey M., and LOTT, Anthony D. (1995) Success and Failure Components of Global Environmental Politics: The Making of International Environmental Law, in ILSA Journal of International and Comparative Law, 2(Fall).

SOUTH AFRICAN DEPARTMENT OF FOREIGN AFFAIRS. (2002) "Speech at the Launch of the African Union, July 9, 2002. [Online]. Available:

http://www.dfa.gov.za/docs/speeches/2002/mbek0709.htm

THE ECONOMIST. “The See-No-Evil Foreign Policy,” The Economist (November 13, 2008). [Online]. Available: http://www.economist.com (accessed January 8, 2009).

UN WATCH. (2007a) "Dawn of a New Era?: Assessment of the UN Human Rights Council and its Year of Reform," UN Watch (May 2007), 27. [Online]. Available: http://www.unwatch.org/atf/cf/\%7B6DEB65DA-BE5B-4CAE-80568BF0BEDF4D17\%7D/DAWN_OF_A_NEW_ERA_HRC\%20REPORT_FINAL.PDF (accessed January 9, 2009).

UN WATCH. (2007b) South Africa's UN Votes Against Human Rights (19 November 2007). [Online]. Available: http://blog.unwatch.org/?p=57.

VALE, Peter, and TAYLOR, Ian. (1999) South Africa's Post-Apartheid Foreign Policy Five Years On - From Pariah State to 'Just Another Country'?, in The Round Table, 352: 629-634.

WALTZ, Kenneth. (1979) Theory of International Politics (London: McGraw Hill).

WILLIAMS, Paul. (2000) South African foreign policy: getting critical?”, in Politikon, 27(1), 73-91

WINES, Michael. (2007) South Africa Lowers Voice on Human Rights," The New York Times, March 24, 2007. 
${ }^{1}$ The authors would like to thank John Nugent for his comments and his editing assistance, as well as the anonymous reviewer for providing helpful feedback.

${ }^{2}$ This was not only the belief of ANC elites. Opinion polls also indicated widespread popular support for a human-rights based foreign policy: "Two-thirds to three-quarters of South African mass respondents are very concerned about human rights abuses in other countries... and want the government to do something about it. This seems to be such an important issue for the majority that more citizens strongly want South Africa to be known as a defender of human rights than strongly want it to be known as the leader of southern Africa" (Nel, Taylor, and van der Westhuizen 2000, 58).

${ }^{3}$ This description of South Africa would seem to be in accordance with Nel, Taylor and Westhuizen's description of middle powers of the South. They argue, among things, that such states, are reformist rather than transformative, may sometimes oppose the hegemon - although they will only be successful in their opposition if the issue at stake is not a core interest for the hegemon - will likely aspire to, and indeed may hold, significant roles in multilateral institutions - at least partly because they provide opportunities for leading Southern coalitions against the hegemon - and are regionally dominant (Nel, et al 2000, 46-7).

${ }^{4}$ South Africa's desire to stand firm with its African brothers does not stem solely from a sense of solidarity in the face of outside condemnation, however. It is also results from a desire not to be itself isolated by other African countries, a lesson it learned the hard way in Nigeria. In 1996, during his first Commonwealth Conference as president, Nelson Mandela called for sanctions to be imposed on Nigeria's authoritarian Abacha regime. Nigeria was suspended by the Conference, but Mandela pressed for more isolation of the Nigerian government, calling for diplomatic isolation, which he led by withdrawing the South African High Commissioner. He also called on Western states to boycott Nigerian oil and called a meeting of SADC to discuss ways to coordinate pressure, only to be roundly denounced by other African leaders there. As Barber notes, African states saw Nigeria not as a human-rights-abusing state, but as a continental leader that had supported liberation struggles. Indeed, "they accused Mandela of breaking African Unity" (Barber 2005, 1084). The lesson was clearly taken to heart, and South Africa was brought back into line: in 2001, when having to justify Mbeki's policy of quiet diplomacy in Zimbabwe, a senior ANC member stated that "South Africa would not repeat Mandela's 'terrible mistake' when he acted as a 'bully' against the Nigerian dictatorship and 'everyone stood aside and we were isolated." Nathan $(2005,367)$. The "Nigerian debacle" (as Bischoff calls it) clearly stung South Africa and seems to have tempered its willingness to act forcefully as a leader in condemning human rights violations on the African continent. 